\title{
Carbonate-silicate ratio for soil correction and influence on nutrition, biomass production and quality of palisade grass
}

\author{
Renato Ferreira de Souza ${ }^{1 *}$, Fabrício William Ávila², Valdemar Faquin², Adélia Aziz \\ Alexandre Pozza ${ }^{2}$, Janice Guedes Carvalho², Antônio Ricardo Evangelista ${ }^{3}$ \\ ${ }^{1}$ EPAMIG/URECO, C.P. 295 - 35701-970 - Prudente de Morais, MG - Brasil. \\ ${ }^{2}$ UFLA - Depto. de Ciência do Solo, C.P. 3037 - 37200-000 - Lavras, MG - Brasil. \\ ${ }^{3} U F L A$ - Depto. de Zootecnia. \\ *Corresponding author <souzarf@epamig.br> \\ Edited by: Luís Reynaldo Ferracciú Alleoni
}

\begin{abstract}
Silicates can be used as soil correctives, with the advantage of being a source of silicon, a beneficial element to the grasses. However, high concentrations of silicon in the plant would affect the digestibility of the forage. To evaluate the influence of the substitution of the calcium carbonate by calcium silicate on the nutrition, biomass production and the feed quality of the palisade grass [Urochloa brizantha (C. Hochstetter ex A. Rich.) R. Webster], three greenhouse experiments were conducted in completely randomized designs with four replications. Experimental units (pots) contained a clayey dystrophic Rhodic Haplustox, a sandy clay loam dystrophic Typic Haplustox and a sandy loam dystrophic Typic Haplustox. Each soil received substitution proportions $(0,25,50,75$ and $100 \%)$ of the carbonate by calcium silicate. The increase in the proportion of calcium silicate elevated the concentrations and accumulations of $\mathrm{Si}, \mathrm{Ca}, \mathrm{Mg}$, and $\mathrm{B}$, reduced $\mathrm{Zn}$ and did not alter $\mathrm{P}$ in the shoot of plants. The effects of the treatments on the other nutrients were influenced by the soil type. Inclusion of calcium silicate also increased the relative nutritional value and the digestibility and ingestion of the forage, while the concentration and accumulation of crude protein and the neutral detergent and acid detergent fibers decreased. Biomass production and feed quality of the palisade grass were generally higher with the $50 \%$ calcium silicate treatment.

Keywords: Urochloa brizantha, pasture, lime, silicon, feed value
\end{abstract}

\section{Introduction}

The Brazilian savannah (cerrado) includes approximately 200 million hectares, $25 \%$ of which are pastures, the majority being Urochloa spp. Between 70 to $80 \%$ of these pastures are at some level of degradation and low productivity (Reis et al., 2010) due to soil limitations such as aluminum toxicity, phosphorus deficiency, and low $\mathrm{pH}$.

Lime application has been the main method for acidity correction because of its low cost, ease of application and increase of plant availability of $\mathrm{Ca}$ and $\mathrm{Mg}$. However, another alternative method used for the acidity correction is the application of silicates, silicon ( $\mathrm{Si}$ ) being also a source for several crops.

Authors have shown beneficial effects of $\mathrm{Si}$ in several vegetable species, especially grasses. Benefits include increased availability of $\mathrm{P}$ and micronutrients in the soil (Marschner, 1995), resistance to pests and diseases (Rodrigues et al., 2004) and tolerance to excess of $\mathrm{Fe}^{2+}$ and $\mathrm{Al}^{3+}$ ions (Mengel and Kirkby, 2001), tolerance to salinity (Matoh et al., 1986) and a more erect disposition of leaves, which increases the photosynthetic rate (Ávila et al., 2010; Yoshida et al., 1962). However, the excess uptake of Si by grasses may provide a higher mechanical resistance to degradation (Melo et al., 2003); reducing their ruminal digestibility (Jones and Handreck, 1967).

For these reasons, the objective of this study was to evaluate the effect of the substitution of calcium carbon- ate by calcium silicate on the nutrition, biomass production and feed quality of palisade grass cultivated in soils with different texture and mineralogical composition.

\section{Materials and Methods}

Three greenhouse experiments were conducted in Lavras, state of Minas Gerais - Brazil, with three types of soil, each comprising a specific experiment. In order to include a wide variation soils with varying physical, chemical and mineralogical attributes were used: sandy loam dystrophic Typic Haplustox (LVAd-1), a sandy clay loam dystrophic Typic Haplustox (LVAd-2), and clayey dystrophic Rhodic Haplustox (LVd) (Embrapa, 2006). They were collected from the $0-20 \mathrm{~cm}$ layer, under natural vegetation, after the removal of the organic remains present on the surface. Later, after sieving through 4-mm mesh sieve, soil subsamples were characterized chemically, physically and mineralogically (Table 1).

Treatments were distributed in a completely randomized design with four replications and included five substitution levels $(0,25,50,75$ and $100 \%)$ of $\mathrm{CaCO}_{3}$ and $\mathrm{MgCO}_{3}$ by $\mathrm{CaSiO}_{3}$ and $\mathrm{MgSiO}_{3}$, and an untreated control. The salts (pa grade) were expressed in $\mathrm{CaCO}_{3}$ equivalent (Alcarde and Rodella, 1996). In all of the treatments a 4:1 stoichiometric ratio of $\mathrm{Ca}: \mathrm{Mg}$ was maintained and supplied in amounts sufficient to elevate the base saturation of each soil to $60 \%$ (Van Raij et al., 1996) (Table 2).

After the application of the treatments and 30 days of incubation, each experimental unit received application of 
Table 1 - Chemical, physical and mineralogical attributes of the soil samples $(0-20 \mathrm{~cm}$ depth), prior to treatments.

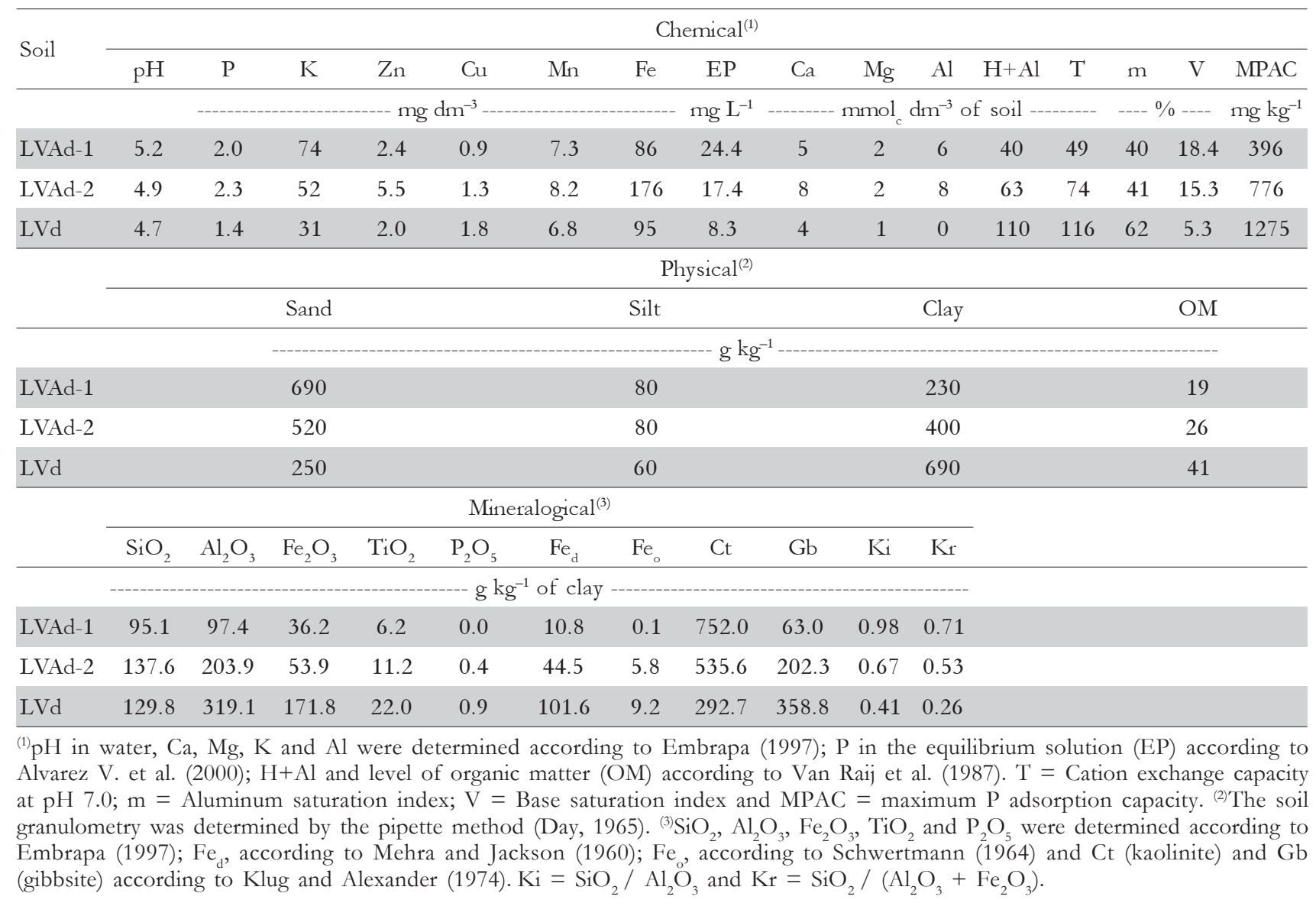

Table 2 - Corrective levels to elevate the base saturation of each soil to $60 \%$, expressed as $\mathrm{CaCO}_{3}$ equivalent: $\mathrm{CaCO}_{3}=$ 1.000; $\mathrm{MgCO}_{3}=1.183 ; \mathrm{CaSiO}_{3}=0.879$ and $\mathrm{MgSiO}_{3}=1.017$.

\begin{tabular}{|c|c|c|c|c|c|c|c|c|}
\hline \multirow{2}{*}{ Soil } & \multirow{2}{*}{ Treatment } & \multicolumn{4}{|c|}{ Corrective } & \multirow{2}{*}{$\mathrm{Ca}$} & \multirow{2}{*}{$\mathrm{Mg}$} & \multirow{2}{*}{$\mathrm{Si}$} \\
\hline & & $\mathrm{CaCO}_{3}$ & $\mathrm{MgCO}_{3}$ & $\mathrm{CaSiO}_{3}$ & $\mathrm{MgSiO}_{3}$ & & & \\
\hline & $\% \mathrm{CaSiO}_{3}$ & & 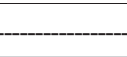 & - & $\mathrm{dm}^{-3}$ & 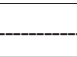 & $\ldots$ & \\
\hline LVAd-1 & 0 & 815 & 172 & 0 & 0 & 320 & 49 & 0 \\
\hline LVAd-1 & 25 & 612 & 129 & 232 & 50 & 320 & 49 & 70 \\
\hline LVAd-1 & 50 & 408 & 86 & 464 & 100 & 320 & 49 & 140 \\
\hline LVAd-1 & 75 & 204 & 43 & 696 & 150 & 320 & 49 & 210 \\
\hline LVAd-1 & 100 & 0 & 0 & 928 & 200 & 320 & 49 & 280 \\
\hline LVAd-2 & 0 & 1323 & 280 & 0 & 0 & 519 & 79 & 0 \\
\hline LVAd-2 & 25 & 992 & 210 & 376 & 81 & 519 & 79 & 114 \\
\hline LVAd-2 & 50 & 662 & 140 & 753 & 163 & 519 & 79 & 227 \\
\hline LVAd-2 & 75 & 331 & 70 & 1129 & 244 & 519 & 79 & 341 \\
\hline LVAd-2 & 100 & 0 & 0 & 1505 & 325 & 519 & 79 & 455 \\
\hline $\mathrm{LVd}$ & 0 & 2538 & 536 & 0 & 0 & 996 & 151 & 0 \\
\hline $\mathrm{LVd}$ & 25 & 1904 & 402 & 722 & 156 & 996 & 151 & 218 \\
\hline $\mathrm{LVd}$ & 50 & 1269 & 268 & 1444 & 312 & 996 & 151 & 436 \\
\hline $\mathrm{LVd}$ & 75 & 635 & 134 & 2166 & 468 & 996 & 151 & 654 \\
\hline $\mathrm{LVd}$ & 100 & 0 & 0 & 2887 & 624 & 996 & 151 & 873 \\
\hline
\end{tabular}

Sci. Agric. (Piracicaba, Braz.), v.68, n.5, p.526-534, September/October 2011 
fertilizers as basal dressing, made up of: $300 \mathrm{mg} \mathrm{dm}^{-3} \mathrm{~N}, 200$ $\mathrm{mg} \mathrm{dm}{ }^{-3} \mathrm{P}, 300 \mathrm{mg} \mathrm{dm}^{-3} \mathrm{~K}, 50 \mathrm{mg} \mathrm{dm}^{-3} \mathrm{~S}, 0.5 \mathrm{mg} \mathrm{dm}^{-3} \mathrm{~B}$, $1.5 \mathrm{mg} \mathrm{dm}^{-3} \mathrm{Cu}, 3.0 \mathrm{mg} \mathrm{dm}^{-3} \mathrm{Mn}, 0.1 \mathrm{mg} \mathrm{dm}^{-3} \mathrm{Mo}, 5.0 \mathrm{mg}$ $\mathrm{dm}^{-3} \mathrm{Zn}$ and $5.0 \mathrm{mg} \mathrm{dm}{ }^{-3} \mathrm{Fe}$; added as solutions of $\mathrm{NH}_{4} \mathrm{H}_{2} \mathrm{PO}_{4}, \mathrm{~K}_{2} \mathrm{SO}_{4}, \mathrm{KNO}_{3}, \mathrm{NH}_{4} \mathrm{NO}_{3}, \mathrm{H}_{3} \mathrm{BO}_{3}, \mathrm{CuSO}_{4} .5 \mathrm{H}_{2} \mathrm{O}$, $\mathrm{ZnSO}_{4} \cdot 7 \mathrm{H}_{2} \mathrm{O}, \mathrm{FeSO}_{4} \cdot 7 \mathrm{H}_{2} \mathrm{O}, \mathrm{MnCl}_{2} \cdot 4 \mathrm{H}_{2} \mathrm{O}$ and $\mathrm{H}_{2} \mathrm{MoO}_{4} \cdot \mathrm{H}_{2} \mathrm{O}$ (pa grade). After each cut, fertilization as top dressing was performed, made up of 240, 170 and $60 \mathrm{mg} \mathrm{dm}^{-3}$ of $\mathrm{N}, \mathrm{K}$ and $\mathrm{S}$, respectively, added as solutions of $\mathrm{NH}_{4} \mathrm{H}_{2} \mathrm{PO}_{4}, \mathrm{~K}_{2} \mathrm{SO}_{4}$ and $\mathrm{KNO}_{3}$ (pa grade). During the experimental period, the soil water content was maintained at around $60 \%$ of the total pore volume by periodically weighing the pots and adding deionized water to compensate for weight loss.

Three plants per pot of 'Vitoria' palisade grass [Urochloa brizantha (C. Hochstetter ex A. Rich.) R. Webster] were cultivated in $4 \mathrm{dm}^{3}$ of soil, which were cut during the pre-flowering developmental phases (90 and 140 days after the seedling emergence). After each cutting, shoots were dried for $72 \mathrm{~h}$ at $60-65^{\circ} \mathrm{C}$ in a forced draught oven, weighed (to obtain dry matter) and triturated in a Wiley-type mill. Biomass obtained from the two cuts were combined to determine the concentration of crude protein (CP) (Silva, 1998), Si (Gallo and Furlani, 1978) and nutrients (Malavolta et al., 1997). Accumulation of $\mathrm{Si}$ and nutrients in plant shoots was measured, from the relationship between biomass production and concentrations of $\mathrm{Si}$ and nutrients, and quantification of the neutral detergent fiber (NDF) and acid detergent fiber (ADF) were carried out according to van Soest (1994). From these values, the dry matter ingestion (DMI $=120 / \% \mathrm{NDF})$, the dry matter digestibility $[\mathrm{DMD}=88.9(0.779 \times \% \mathrm{ADF})]$ and the relative feed value $(\mathrm{RFV}=\mathrm{DMD} \times \mathrm{DMI} / 1.29)$ of the forage were estimated according to American Forage and Grassland Council (Ensminger, 1993).

Data were submitted to the variance analysis by the F test $(p \leq 0.05)$ using the SISVAR software (Ferreira, 2008). When significant, the effect of the calcium silicate on the variables was verified by polynomial regression analysis.

\section{Results and Discussion}

Dry matter production was similar for the first and second cuts and the total of the two cuts (TDM) had similar behavior. In general, the $50 \%$ substitution of $\mathrm{CaCO}_{3}$ by $\mathrm{CaSiO}_{3}$ promoted higher benefits in the production of TDM, which was increased by 2.6, 15.2 and $19.5 \%$ for the LVAd-1, LVAd-2 and LVd soils, respectively, compared to the treatments that only received $\mathrm{CaCO}_{3}$ (Figure 1). Most likely the increase in biomass, particularly for the plants cultivated on LVAd-2 and LVd, was due to the silicon (Si) added to the soil by $\mathrm{CaSiO}_{3}$. Marschner (1995) found Si does not have a defined metabolic role in the plants, however, its action provokes indirect effects, which, when combined can contribute to a higher vegetative production. Silicon accumulation in epidermal cells of the plant shoot promotes a better leaf opening angle, making them more erect, reduces selfshading favoring a better light use and it elevates the photosynthetic rate, culminating in higher biomass production

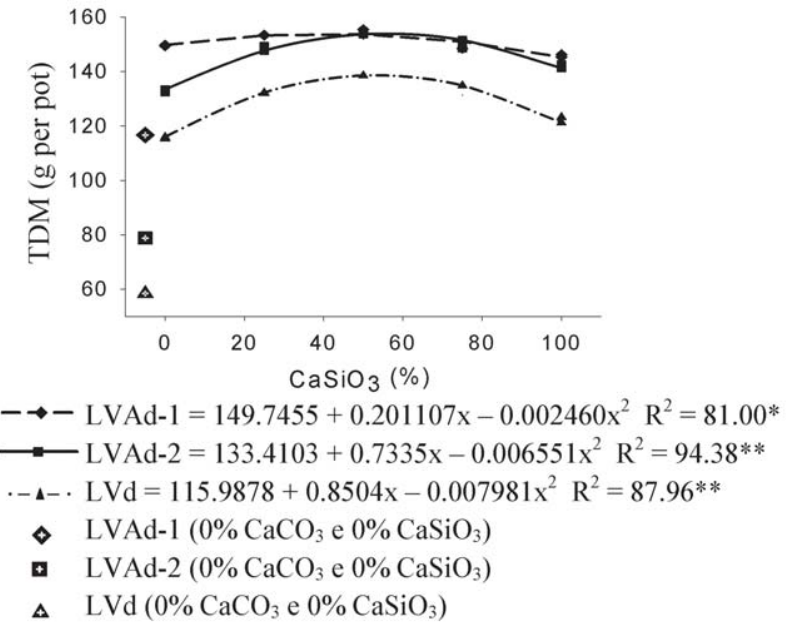

Figure 1 - Production of total dry matter (TDM) for palisade grass shoots cultivated on LVAd-1, LVAd-2 and LVd soils, as a function of substitution proportions of the calcium carbonate by calcium silicate. $*$ and $* *=p \leq$ 0.05 and $p \leq 0.01$, respectively.

(Yoshida et al., 1962). Other beneficial effects of Si in grasses have also been noted, such as reduced transpiration (Dayanandam et. al., 1983) and nutrient imbalance (Marschner, 1995; McKeague and Cline, 1963), and increased protection against UV radiation (Tisdale et al., 1993), pest and disease resistance (Rodrigues et al., 2004) and antioxidant enzyme activity (Liang et al., 2003).

In general, the effect of treatments on biomass production was less evident for LVAd-1, probably due its lower clay content (Table 1). Dry matter production by the control $\left(0 \% \mathrm{CaCO}_{3}\right.$ and $\left.0 \% \mathrm{CaSiO}_{3}\right)$ was inferior to the other treatments, which shows the importance of soil correction for palisade grass production.

The concentrations and accumulations of calcium (Ca) and magnesium ( $\mathrm{Mg}$ ) in palisade grass shoots (Figure 2 and Table 3 ) increased considerably with increasing proportions of $\mathrm{CaSiO}_{3}$ up to an average of $65 \%$. This behavior can be due to the higher reactivity of the silicates (Lackner, 2002; Ramos et al., 2006). Alcarde and Rodella (2003) found $\mathrm{CaSiO}_{3}$ to be 6.78 times more soluble than $\mathrm{CaCO}_{3}$. These factors could have contributed to increasing the absorption of these nutrients due to higher availability of $\mathrm{Ca}$ and $\mathrm{Mg}$ to the palisade grass. Kaya et al. (2006) and Mali and Aery (2008) verified increases in the concentrations of $\mathrm{Ca}$ in corn (Zea mays) and cowpea (Vigna unguiculata), respectively, with application of silicates to the soil, in agreement with the results obtained in this work.

The accumulations of $\mathrm{Ca}$ and $\mathrm{Mg}$ in palisade grass shoots, in the soil without correction $\left(0 \% \mathrm{CaCO}_{3}\right.$ and $0 \%$ $\mathrm{CaSiO}_{3}$ ), was generally similar to treatments that received only $\mathrm{CaCO}_{3}$. This shows that soil correction with only $\mathrm{CaCO}_{3}$ had little influence on the $\mathrm{Ca}$ and $\mathrm{Mg}$ absorption by the palisade grass. Concentrations of exchangeable $\mathrm{Ca}^{2+}$ and $\mathrm{Mg}^{2+}$ in the three soils without correction (Table 1) were in the ranges considered by van Raij et al. (1996) as average 

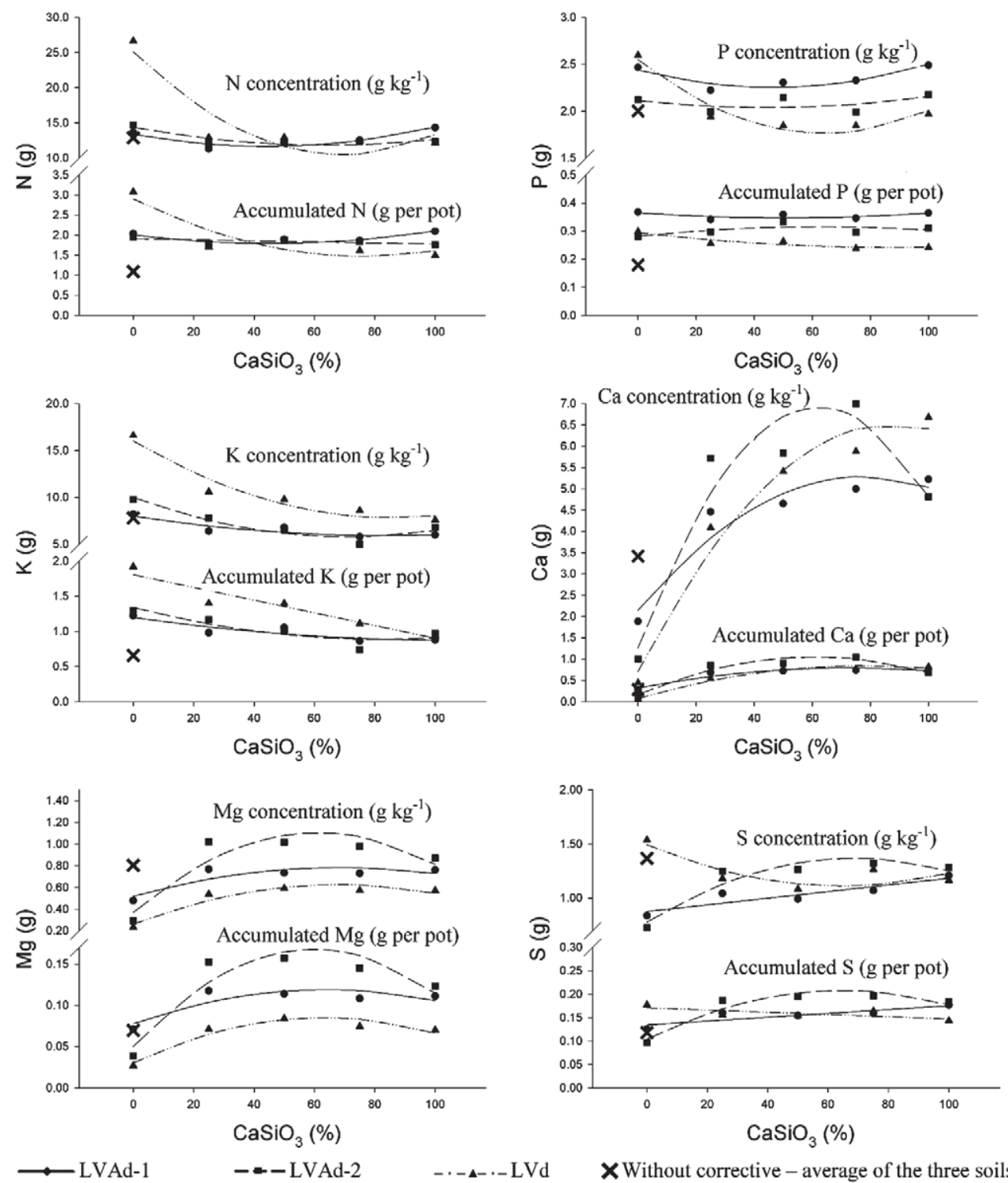

Figure 2 - Concentration and accumulation of macronutrients for palisade grass shoots cultivated on LVAd-1, LVAd-2 and LVd soils, as a function of substitute proportions of the calcium carbonate by calcium silicate.

(4-7 $\mathrm{mmol}_{\mathrm{c}}$ of $\left.\mathrm{Ca}^{+2} \mathrm{dm}^{-3}\right)$ and low $\left(0-4 \mathrm{mmol}_{\mathrm{c}}\right.$ of $\mathrm{Mg}^{+2}$ $\mathrm{dm}^{-3}$ ), respectively.

The concentration and the accumulation of nitrogen $(\mathrm{N})$, potassium $(\mathrm{K})$ and sulfur $(\mathrm{S})$ in the shoot of the palisade grass (Figure 2 and Table 3), when cultivated in $\mathrm{LVd}$, decreased as the $\mathrm{CaSiO}_{3}$ proportions increased, until an average value of $70 \%$ of $\mathrm{CaSiO}_{3}$, when it tended to stabilize. Calcium silicate at $70 \%$ of the correction for $\mathrm{LVd}$ reduced the concentrations of $\mathrm{N}, \mathrm{K}$ and $\mathrm{S}$ to 58,49 and $25 \%$, respectively, and their accumulations to 58,49 and $9 \%$, respectively. However, for the plants cultivated in LVAd-1 and LVAd-2, the concentrations and accumulations of these nutrients were mostly unaffected. Conversely, $\mathrm{S}$ increased in shoots as $\mathrm{CaSiO}_{3}$ increased. $\mathrm{LVd}$ has a higher cation exchange capacity (CEC) and levels of organic matter, gibbsite, iron oxides and clay, compared to the other appraised soils (Table 1). This partly explains the differentiated behavior of the plants as to the N, K and $\mathrm{S}$ absorption as a function of soil type. For instance, the higher CEC of LVd demanded a higher amount of correctives to elevate the base saturation to $60 \%$. This resulted in a larger amount of $\mathrm{Si}$ being added with $\mathrm{CaSiO}_{3}$. Wallace (1989) reports that for the absorption sites of the plant there is competition among the anions $\mathrm{H}_{3} \mathrm{SiO}_{4}^{-}$and $\mathrm{NO}_{3}^{-}$. The lower accumulation of $\mathrm{K}$ and $\mathrm{S}$ observed with increased $\mathrm{CaSiO}_{3}$ proportions can likely be explained by the higher solubility of $\mathrm{CaSiO}_{3}$ compared to $\mathrm{CaCO}_{3}$, which increases soil solution $\mathrm{Ca}^{2+}$ and $\mathrm{Mg}^{2+}$, antagonism for the absorption of $\mathrm{K}^{+}$(Malavolta et al., 1997), and low solubility $\mathrm{SO}_{4}^{2-}$. To reiterate, accumulations of $\mathrm{N}$ and $\mathrm{K}$ in the shoot of the palisade grass were lower when soils did not receive correctives, showing the influence of correctives on $\mathrm{N}$ and $\mathrm{K}$ absorption by the palisade grass, regardless of soil type. 
Table 3 - Regression equations for concentration and accumulation of macronutrients in palisade grass shoots cultivated on LVAd-1, LVAd-2 and LVd soils, as a function of substitute proportions of the calcium carbonate by calcium silicate.

\begin{tabular}{|c|c|c|c|}
\hline Factor & Soils & Regression equation for concentration & Regression equation for accumulation \\
\hline $\mathrm{N}$ & LVAd-1 & $\hat{y}=13.3848-0.0780 x+0.000884 x^{2} \quad R^{2}=87.28 * *$ & $\hat{y}=2.0024-0.0092 x+0.000102 x^{2} \quad R^{2}=75.52 *$ \\
\hline $\mathrm{N}$ & LVAd-2 & $\hat{y}=14.3781-0.0793 x+0.000617 x^{2} \quad R^{2}=78.34^{*}$ & $\hat{y}=1.9117-0.00134 x \quad R^{2}=50.62 n s$ \\
\hline $\mathrm{N}$ & $\mathrm{LVd}$ & $\hat{\mathrm{y}}=25.0981-0.4196 \mathrm{x}+0.003017 \mathrm{x}^{2} \quad \mathrm{R}^{2}=86.38^{* *}$ & $\hat{y}=2.9056-0.0374 x+0.000244 x^{2} \quad R^{2}=83.46^{* *}$ \\
\hline $\mathrm{P}$ & LVAd-1 & $\hat{y}=2.4397-0.0080 x+0.000086 x^{2} \quad R^{2}=83.51 n s$ & $\hat{y}=0.3649-0.0007 x+0.000007 x^{2} \quad R^{2}=47.27 n s$ \\
\hline $\mathrm{P}$ & LVAd-2 & $\hat{y}=2.1114-0.0033 x+0.000037 x^{2} \quad R^{2}=28.64 n s$ & $\hat{y}=0.2815+0.0011 x-0.000009 x^{2} \quad R^{2}=50.02 n s$ \\
\hline $\mathrm{P}$ & LVd & $\hat{y}=2.5477-0.0243 x+0.000189 x^{2} \quad R^{2}=94.40 * *$ & $\hat{y}=0.2948-0.0012 x+0.000007 x^{2} \quad R^{2}=85.74 n s$ \\
\hline K & LVAd-1 & $\hat{y}=8.0114-0.0497 x+0.000297 x^{2} \quad R^{2}=82.13 n s$ & $\hat{y}=1.1976-0.0061 x+0.000028 x^{2} \quad R^{2}=80.06 n s$ \\
\hline $\mathrm{K}$ & LVAd-2 & $\hat{y}=2.4397-0.0080 x+0.000086 x^{2} \quad R^{2}=91.72 *$ & $\hat{y}=1.3389-0.0110 x+0.000067 x^{2} \quad R^{2}=79.72 *$ \\
\hline K & LVd & $\hat{y}=16.0114-0.1897 x+0.001097 x^{2} \quad R^{2}=93.86^{* *}$ & $\hat{\mathrm{y}}=1.8058-0.009041 \mathrm{x} \quad \mathrm{R}^{2}=91.34^{* *}$ \\
\hline $\mathrm{Ca}$ & LVAd-1 & $\hat{y}=2.1517+0.0807 x-0.000519 x^{2} \quad R^{2}=91.44^{* *}$ & $\hat{y}=0.3230+0.0130 x-0.000089 x^{2} \quad R^{2}=90.77 * *$ \\
\hline $\mathrm{Ca}$ & LVAd-2 & $\hat{y}=1.2679+0.1817 x-0.001461 x^{2} \quad R^{2}=92.54^{* *}$ & $\hat{y}=0.1696+0.0288 x-0.000237 x^{2} \quad R^{2}=94.23 * *$ \\
\hline $\mathrm{Ca}$ & $\mathrm{LVd}$ & $\hat{\mathrm{y}}=0.71196+0.1319 \mathrm{x}-0.000748 \mathrm{x}^{2} \quad \mathrm{R}^{2}=97.10^{* *}$ & $\hat{y}=0.0783+0.0197 x-0.000126 x^{2} \quad R^{2}=97.08^{* *}$ \\
\hline $\mathrm{Mg}$ & LVAd-1 & $\hat{y}=0.5194+0.0077 x-0.000056 x^{2} \quad R^{2}=75.55^{* *}$ & $\hat{\mathrm{y}}=0.0777+0.0013 \mathrm{x}-0.000010 \mathrm{x}^{2} \quad \mathrm{R}^{2}=74.45^{* *}$ \\
\hline $\mathrm{Mg}$ & LVAd-2 & $\hat{\mathrm{y}}=0.3712+0.0239 \mathrm{x}-0.000195 \mathrm{x}^{2} \quad \mathrm{R}^{2}=86.44 * *$ & $\hat{y}=0.0502+0.0039 x-0.000033 x^{2} \quad R^{2}=88.53 * *$ \\
\hline $\mathrm{Mg}$ & $\mathrm{LVd}$ & $\hat{y}=0.2619+0.0107 x-0.000078 x^{2} \quad R^{2}=91.95^{* *}$ & $\hat{y}=0.0304+0.0017 x-0.000014 x^{2} \quad R^{2}=92.93^{* *}$ \\
\hline $\mathrm{S}$ & LVAd-1 & $\hat{\mathrm{y}}=0.8760+0.003073 \mathrm{x} \quad \mathrm{R}^{2}=82.09^{* *}$ & $\hat{\mathrm{y}}=0.1344+0.000411 \mathrm{x} \mathrm{R}^{2}=74.88^{* *}$ \\
\hline S & LVAd-2 & $\hat{y}=0.7782+0.0107 x-0.000123 x^{2} \quad R^{2}=90.43^{* *}$ & $\hat{y}=0.1042+0.0032 x-0.000025 x^{2} \quad R^{2}=92.51 * *$ \\
\hline $\mathrm{S}$ & LVd & $\hat{\mathrm{y}}=1.4918-0.0117 \mathrm{x}+0.000091 \mathrm{x}^{2} \quad \mathrm{R}^{2}=72.31^{* *}$ & $\hat{y}=0.1709-0.000239 x \quad R^{2}=55.68^{*}$ \\
\hline
\end{tabular}

As for the phosphorus $(\mathrm{P}), \mathrm{CaSiO}_{3}$ proportions, up to an average of $64 \% \mathrm{CaSiO}_{3}$, decreased $\mathrm{P}$ concentration in palisade grass shoots for the LVd (Figure 2 and Table 3). However, the $\mathrm{P}$ accumulation (Figure 2 and Table 3 ) was not significant $(p>0.05)$ among treatments, showing that a lower $\mathrm{P}$ concentration was likely due to the "dilution" effect, which is confirmed by the higher shoot dry matter production observed for the $60 \% \mathrm{CaSiO}_{3}$ treatment (Figure 1). For example, when plant production increases, the "dilution" effect for some nutrients can occur (Crusciol et al., 2008; Marschner, 1995; Miyauchi at al., 2008), which is the reduction of their concentration in the tissue without an alteration in the absorbed quantity. Still, the concentration of $\mathrm{P}$ in the plants cultivated on LVAd-1 and LVAd-2 were not different either among treatments. This shows that for $\mathrm{P}$, the substitution of $\mathrm{CaCO}_{3}$ by $\mathrm{CaSiO}_{3}$, in any proportion, does not influence its absorption by palisade grass. Tokura et al. (2007) also verified no effect of silicon doses on $\mathrm{P}$ uptake for upland rice (Oryza sativa L.) grown on dystroferric Rhodic Acrustox and orthic Ustic Quartzipsamments.

The accumulation of $\mathrm{P}$ was much lower in relation to the other plants for palisade grass cultivated in soil without correction. The elevation of the $\mathrm{pH}$ promoted by soil correction increases the concentration and activity of the $\mathrm{OH}^{-}$ ion in solution, generating negative charges for the deprotonation of hydroxyls in the exposed clay and organic matter. Thus, the repulsion between orthophosphate ions and the soil mineral particles increases, allowing more $\mathrm{P}$ to stay in solution and remain available for plant uptake, especially in soils with high oxide and clay levels. The precipita- tion of $\mathrm{Fe}$ and $\mathrm{Al}$ reduces the formation of low solubility $\mathrm{P}-\mathrm{Fe}$ and P-Al compounds (Novais and Smyth, 1999).

Concentrations and accumulations of the cationic micronutrients in the shoot of the palisade grass (Figure 3 and Table 4) tended to reduce with the elevation of the $\mathrm{CaSiO}_{3}$ proportions, particularly for $\mathrm{Zn}$. Besides the direct effect of silicate, the increased absorption of $\mathrm{Ca}^{2+}$ and $\mathrm{Mg}^{2+}$ by palisade grass with increased proportions of $\mathrm{CaSiO}_{3}$ could have been one of the causes of lower $\mathrm{Zn}^{2+}$ absorption, as Malavolta et al. (1997) found competitive inhibition among those nutrients for plant absorption sites. Concentration and accumulation of $\mathrm{Cu}$ were decreased only for plants cultivated on LVd. Malavolta et al. (1997) also mentioned $\mathrm{Ca}^{2+}$ can impede the exaggerated absorption of $\mathrm{Cu}^{2+}$. The effects of the treatments on the concentrations and accumulations of $\mathrm{Mn}$ and $\mathrm{Fe}$ were also influenced by the soil type. Decreased accumulations of these nutrients in the shoot of the plants were significant only for those cultivated on LVAd-1. Silicon can increase the paerenchyma quantity and diameter in the grasses elevating the oxidant power of the roots, therefore reducing the availability of $\mathrm{Mn}^{2+}$ and $\mathrm{Fe}^{2+}$ (Korndörfer et al., 1999; Marschner, 1995).

Boron concentration and accumulation (Figure 3 and Table 4) increased as $\mathrm{CaSiO}_{3}$ proportions were elevated in the three soils, until an average value of $57 \% \mathrm{CaSiO}_{3}$, thereafter decreasing in plants cultivated on LVd and LVAd-1 soils. In comparison, the $\mathrm{CaSiO}_{3}$ proportion of $57 \%$ in the correction of LVAd-1, LVAd-2 and LVd promoted increases of 71,30 and $53 \%$ in the B concentration, respectively, and 74 , 34 and $85 \%$ in the accumulation, respectively, in shoots. Marschner (1995) mentioned $\mathrm{H}_{4} \mathrm{SiO}_{4}$ and $\mathrm{H}_{3} \mathrm{BO}_{3}$, which are 

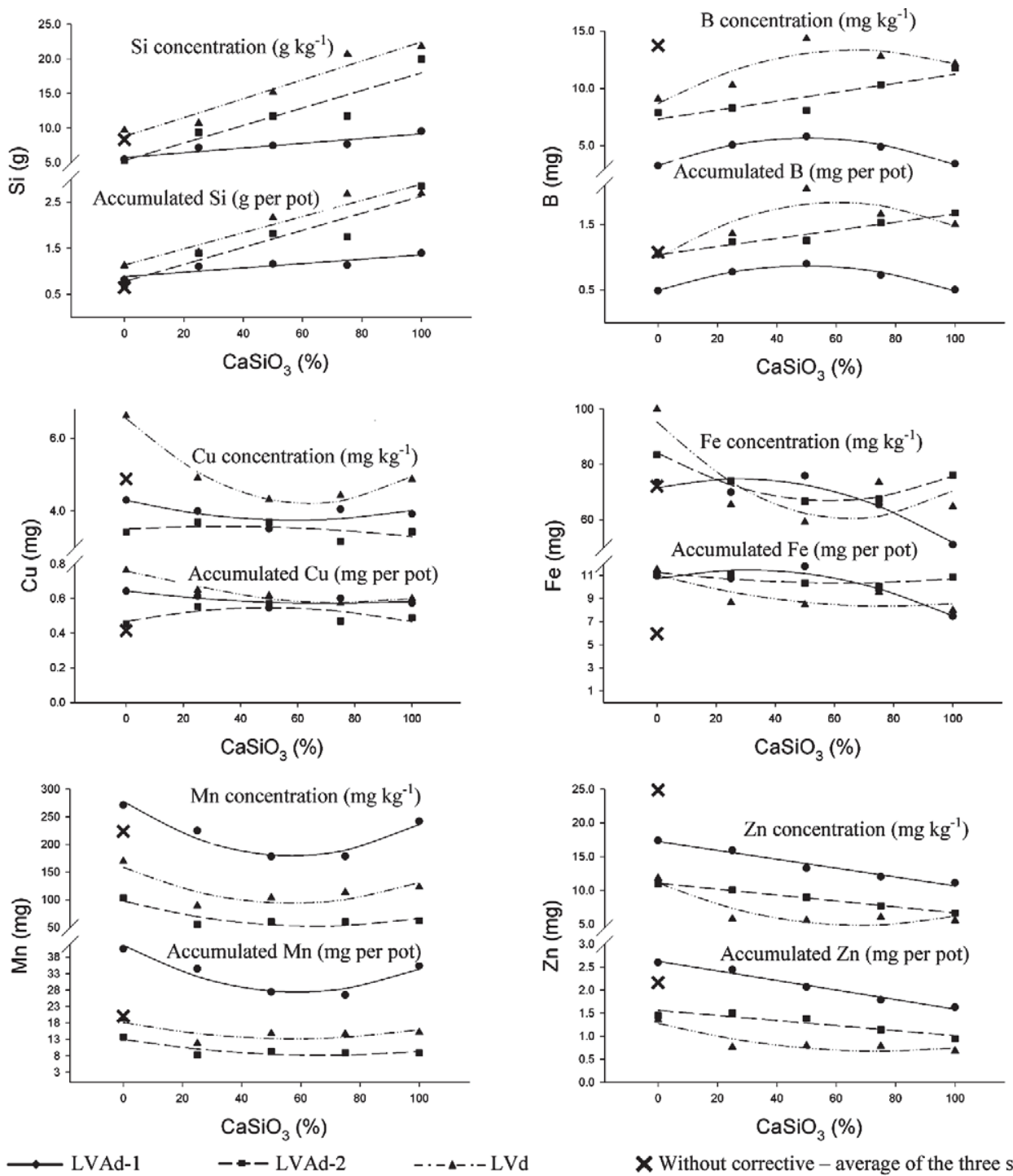

$\mathbf{X}$ Without corrective - average of the three soils

Figure 3 - Concentration and accumulation of micronutrients and Si for palisade grass shoots cultivated on LVAd-1, LVAd-2 and LVd soils, as a function of substitute proportions of the calcium carbonate by calcium silicate.

the main forms of Si and B absorbed by plants, present some similarities as to their behavior in soil solution and plant tissue; both acids are very weak in aqueous solutions and, in the plant, they concentrate in the cell wall, interacting with pectins and polyphenols.

Silicon concentration and accumulation (Figure 3 and Table 4) increased linearly with the elevation of the $\mathrm{CaSiO}_{3}$ proportions in the three soils. Plants cultivated on LVd and LVAd-2 had a higher rate of increase in Si content with increased $\mathrm{CaSiO}_{3}$, compared to those cultivated on LVAd-1. The range of $\mathrm{Si}$ concentration was between 5 to $23 \mathrm{~g} \mathrm{~kg}^{-1}$ of $\mathrm{Si}$, which is equal to $1.1-4.9 \%$ of $\mathrm{SiO}_{2}$, a range considered appropriate by Marschner (1995) for grasses grown on nonflooded soil.

Concentration and accumulation of $\mathrm{Si}$ in the soil without correction were similar to those of plants that received only $\mathrm{CaCO}_{3}\left(0 \% \mathrm{CaSiO}_{3}\right.$ treatment $)$, regardlees of the soil type. As a result, it is explicit that the additional Si absorbed by palisade grass in treatments that received $\mathrm{CaSiO}_{3}$ originated from this source. These results corroborate those of Melo et al. (2003) who also verified increases in concentration and accumulation of $\mathrm{Si}$ in the palisade grass shoots with the application of this element to the soil.

The substitution of the $\mathrm{CaCO}_{3}$ by $\mathrm{CaSiO}_{3}$ promoted decreased crude protein (CP) concentration in palisade grass shoots for plants cultivated on the $\mathrm{LVd}$. The highest $\mathrm{CaSiO}_{3}$ proportion also provided reduced NDF and ADF, consequently, resulting in an increase of the estimated values of dry matter digestibility (DMD), dry matter ingestion (DMI) and relative feed value (RFV) of the forage (Figure 4). According to Ensminger (1993) DMD and DMI values of forage are correlated with the concentrations of $\mathrm{ADF}$ and NDF, respectively.

Thus, the increased concentration and accumulation of Si (Figures 2 and 3) did not result in reduction of forage feed quality. To the contrary, an increase in RFV was observed 
Table 4 - Regression equations for concentration and accumulation of micronutrients and Si in palisade grass shoots cultivated on LVAd-1, LVAd-2 and LVd soils, as a function of substitute proportions of the calcium carbonate by calcium silicate.

\begin{tabular}{|c|c|c|c|}
\hline Factor & Soils & Regression equation for concentration & Regression equation for accumulation \\
\hline $\mathrm{Si}$ & LVAd-1 & $\hat{\mathrm{y}}=5.7469+0.034235 \quad \mathrm{R}^{2}=88.17 * *$ & $\hat{\mathrm{y}}=0.8853+0.0047 \mathrm{x} \quad \mathrm{R}^{2}=83.00^{*}$ \\
\hline $\mathrm{Si}$ & LVAd-2 & $\hat{y}=5.3067+0.126664 R^{2}=87.64 * *$ & $\hat{\mathrm{y}}=0.7781+0.0185 \mathrm{x} \quad \mathrm{R}^{2}=88.99 * *$ \\
\hline Si & $\mathrm{LVd}$ & $\hat{y}=8.7785+0.136692 x \quad R^{2}=94.80 * *$ & $\hat{\mathrm{y}}=1.1360+0.0176 \mathrm{x} \quad \mathrm{R}^{2}=93.17^{* *}$ \\
\hline $\mathrm{B}$ & LVAd-1 & $\hat{y}=3.2883+0.0944 x-0.000937 x^{2} \quad R^{2}=98.62 * *$ & $\hat{y}=0.4935+0.0150 x-0.000151 x^{2} \quad R^{2}=97.25^{* *}$ \\
\hline $\mathrm{B}$ & LVAd-2 & $\hat{\mathrm{y}}=7.32427+0.039041 \mathrm{x} \quad \mathrm{R}^{2}=82.53 * *$ & $\hat{y}=0.0388+0.0062 x \quad R^{2}=95.30 * *$ \\
\hline $\mathrm{B}$ & $\mathrm{LVd}$ & $\hat{\mathrm{y}}=8.6814+0.1406 \mathrm{x}-0.001059 \mathrm{x}^{2} \quad \mathrm{R}^{2}=79.38^{* *}$ & $\hat{\mathrm{y}}=0.9917+0.0279 \mathrm{x}-0.000231 \mathrm{x}^{2} \quad \mathrm{R}^{2}=96.79 * *$ \\
\hline $\mathrm{Cu}$ & LVAd-1 & $\hat{y}=4.2037-0.0185 x+0.000157 x^{2} \quad R^{2}=56.02 n s$ & $\hat{y}=0.6431-0.0020 x+0.000014 x^{2} \quad R^{2}=61.01 n s$ \\
\hline $\mathrm{Cu}$ & LVAd-2 & $\hat{y}=3.5069+0.0041 x-0.000062 x^{2} \quad R^{2}=23.82 n s$ & $\hat{y}=0.4691+0.0032 x-0.000032 x^{2} \quad R^{2}=51.67 n s$ \\
\hline $\mathrm{Cu}$ & LVd & $\hat{y}=6.5403-0.0723 x+0.000571 x^{2} R^{2}=98.18^{* *}$ & $\hat{y}=0.7600-0.0047 x+0.000031 x^{2} R^{2}=97.92 *$ \\
\hline $\mathrm{Fe}$ & LVAd-1 & $\hat{y}=71.5174+0.2407 x-0.004383 x^{2} \quad R^{2}=90.02 n s$ & $\hat{y}=10.7065+0.0506 x-0.000826 x^{2} \quad R^{2}=91.28^{*}$ \\
\hline $\mathrm{Fe}$ & LVAd-2 & $\hat{y}=84.2069-0.5941 x+0.005090 x 2 R^{2}=97.90 n s$ & $\hat{y}=11.2636-0.0295 x+0.000236 x^{2} R^{2}=57.33 n s$ \\
\hline $\mathrm{Fe}$ & $\mathrm{LVd}$ & $\hat{y}=95.3400-1.0723 x+0.008232 x^{2} \quad R^{2}=72.80 *$ & $\hat{y}=11.0183-0.0692 x+0.000444 x^{2} R^{2}=62.83 n s$ \\
\hline $\mathrm{Mn}$ & LVAd-1 & $\hat{y}=278.0420-3.4624 x+0.030440 x^{2} R^{2}=93.71 * *$ & $\hat{y}=41.6557-0.4835 x+0.004105 x^{2} R^{2}=91.49 * *$ \\
\hline $\mathrm{Mn}$ & LVAd-2 & $\hat{y}=97.8774-1.4099 x+0.010945 x^{2} \quad R^{2}=80.44 n s$ & $\hat{y}=13.0046-0.1427 x+0.001061 x^{2} R^{2}=74.42 n s$ \\
\hline Mn & LVd & $\hat{y}=158.7883-2.2849 x+0.020091 x^{2} \quad R^{2}=71.75^{*}$ & $\hat{y}=18.1686-0.1720 x+0.001496 x^{2} R^{2}=51.46 n s$ \\
\hline $\mathrm{Zn}$ & LVAd-1 & $\hat{y}=17.2540-0.065800 x \quad R^{2}=96.90^{* *}$ & $\hat{y}=2.6259-0.010392 x \quad R^{2}=98.02 * *$ \\
\hline $\mathrm{Zn}$ & LVAd-2 & $\hat{\mathrm{y}}=11.0620-0.04400 \mathrm{x} \quad \mathrm{R}^{2}=99.62^{* *}$ & $\hat{\mathrm{y}}=1.5587-0.005481 \mathrm{x} \quad \mathrm{R}^{2}=84.88^{* *}$ \\
\hline $\mathrm{Zn}_{\mathrm{n}}$ & $\mathrm{LVd}$ & $\hat{\mathrm{y}}=11.1003-0.1841 \mathrm{x}+0.001347 \mathrm{x}^{2} \quad \mathrm{R}^{2}=84.00^{* *}$ & $\hat{\mathrm{y}}=1.2780-0.01618 \mathrm{x}+0.000108 \mathrm{x}^{2} \quad \mathrm{R}^{2}=81.09 *$ \\
\hline
\end{tabular}

with up to $50 \%$ of substitution of the $\mathrm{CaCO}_{3}$ by $\mathrm{CaSiO}_{3}$. These results are corroborated by those of Minson (1990) and van Soest (1994) who did not find negative correlation between Si concentration and forage digestibility. Forage quality is directly related to its nutritional composition, anti-nutritional factors and those which are usually involved in plant protection against the predation and degradation (van Soest, 1994). Garleb et al. (1988) found decreased forage digestibility as the lignin concentration increased.

There is no consensus regarding the effect of $\mathrm{Si}$ on forage quality (van Soest, 1994), due to the fact that plants with different Si concentrations also have different composition of other components such as lignin concentration, carbon to nitrogen ratio and differentiated arrangements of cellulose fibrils, which could affect the forage digestibility. Minson (1971) found that Si caused lignin reduction in leaf tissues due to the similar role of both in strengthening cell walls.

The presence of $\mathrm{Si}$ in the forage is of great interest because it is considered an essential element for animals being a component of mucopolysaccharides in connective tissues. In herbivores the ingestion of high amounts of phytoliths can cause excessive abrasion in the rumen wall and the dissolved Si can form kidney concretions, causing serious damage to the livestock (Marschner, 1995).

\section{References}

Alcarde, J.C.; Rodella, A.A. 1996. The calcium carbonate equivalent of agricultural liming materials. Scientia Agricola 53: 6-12. (in Portuguese, with abstract in English).
Alcarde, J.C.; Rodella, A.A. 2003. Quality and legislation of fertilizers and correctives. p. 291-334. In: Curi, N.; Marques, J.J.; Guilherme, L.R.G.; Lima, J.M.; Lopes, A.S.; Alvares Venegas, V.H, eds. Topics in soil science. Sociedade Brasileira de Ciência do Solo, Viçosa, MG, Brazil. (in Portuguese).

Alvarez V., V.H.; Novais, R.F.; Dias, L.E.; Oliveira, J.A. 2000. Determination and utilization of solution equilibrium phosphorus. Boletim Informativo da Sociedade Brasileira de Ciência do Solo 25: 27-32. (in Portuguese).

Ávila, F.W.; Baliza, D.P.; Faquin, V.; Araújo, J.L.; Ramos, S.J. 2010. Siliconnitrogen interaction in rice cultivated under nutrient solution. Revista Ciência Agronômica 41: 184-190. (in Portuguese, with abstract in English).

Crusciol, C.A.C.; Arf, O.; Soratto, R.P.; Mateus, G.P. 2008. Grain quality of upland rice cultivars in response to cropping systems in the Brazilian Tropical Savanna. Scientia Agricola 65: 468-473.

Dayanandam, P.; Kaufman, P.B.; Frankin, C.I. 1983. Detection of silica in plants. American Journal of Botany 70: 1079-1084.

Empresa Brasileira de Pesquisa Agropecuária [EMBRAPA]. 1997. Methods of Soil Analysis. 2ed. Centro Nacional de Pesquisa de Solos, Rio de Janeiro, RJ, Brazil. (in Portuguese).

Empresa Brasileira de Pesquisa Agropecuária [EMBRAPA]. 2006. Brazilian System of Soil Classification. 2ed. Centro Nacional de Pesquisa de Solos, Rio de Janeiro, RJ, Brazil. (in Portuguese).

Ensminger, M.E. 1993. Dairy Cattle Science. 3ed. Interstate, Danville, IL, USA.

Ferreira, D.F. 2008. SISVAR: a program for statistical analysis and teaching. Revista Symposium 6: 36-41. (in Portuguese, with abstract in English).

Gallo, J.R.; Furlani, P.R. 1978. Determination of silicon in plants by the molibdenum-blue colorometric method. Bragantia 37: 5-11. (in Portuguese, with abstract in English).

Garleb, K.A.; Fahey Jr., G.Ñ.; Lewis, S.M.; Kerley, S.M.; Montgomery, L. 1988. Chemical composition and digestibility of fiber fractions of certain by-product feedstuffs fed to ruminants. Journal of Animal Science 66: 2650-2662. 


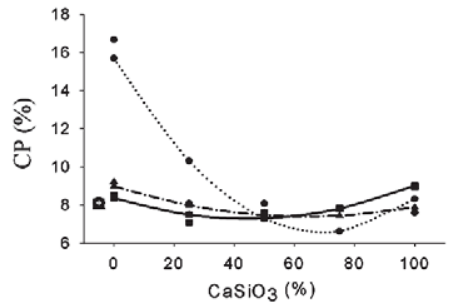

$\mathrm{CP}_{\text {LVAd-1 }}=8.365619-0.048724 \mathrm{x}+0.000552 \mathrm{x}^{2} \mathrm{R}^{2}=0.87 * *$ $\mathrm{CP}_{\text {LVAd-2 }}=8.986248-0.049562 \mathrm{x}+0.000386 \mathrm{x}^{2} \mathrm{R}^{2}=0.78^{* *}$ $\mathrm{CP}_{\mathrm{LVd}}=15.686295-0.262233 \mathrm{x}+0.001886 \mathrm{x}^{2} \mathrm{R}^{2}=0.86 * *$

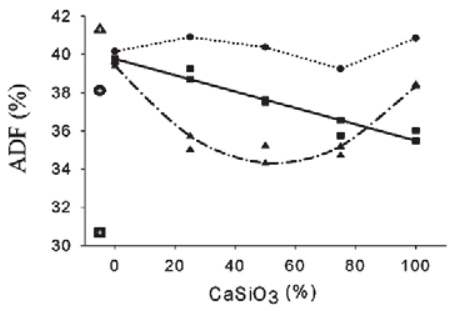

$\mathrm{ADF}_{\text {LVAd-1 }}=30.76720-0.04278 \times \mathrm{R}^{2}=0.90^{* *}$ $\mathrm{ADF}_{\mathrm{LVAd}-2}=39.40728-0.19283 \mathrm{x}+0.00182 \mathrm{x}^{2} \mathrm{R}^{2}=0.92 * *$ $\mathrm{ADF}_{\mathrm{LVd}}=$ non-adjusted model

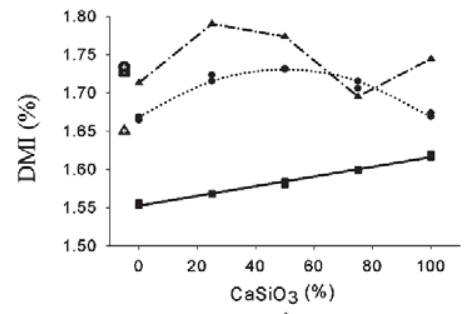

$\mathrm{DMI}_{\text {LVAd } 1}=1.55280+0.00063 \mathrm{x} \mathrm{R}^{2}=0.98 * *$

$\mathrm{DMI}_{\mathrm{LVAd-2}-2}=$ non-adjusted model

$\operatorname{DMI}_{\mathrm{LVd}_{\mathrm{d}}}=1.66885+0.00248 \mathrm{x}-0.00003 \mathrm{x}^{2} \mathrm{R}^{2}=0.95^{* *}$

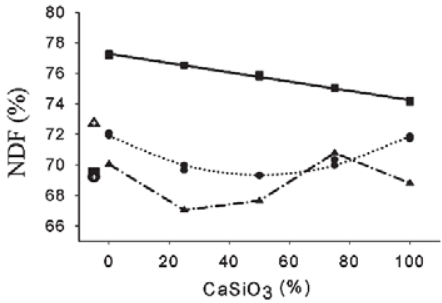

$\mathrm{NDF}_{\text {LVAd-1 }}=77.27653-0.03028 \mathrm{x} \mathrm{R}^{2}=0.98^{* *}$

$\mathrm{NDF}_{\mathrm{LVAd}-2}=$ non-adjusted model

$\mathrm{NDF}_{\mathrm{LVd}}=71.92246-0.10327 \mathrm{x}+0.00103 \mathrm{x}^{2} \mathrm{R}^{2}=0.95 * *$

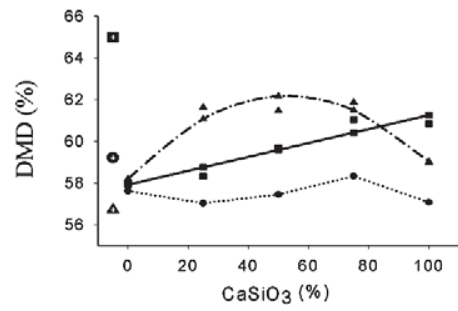

DMD $_{\text {LVAd-I }}=57.92120+0.03333 \mathrm{R}^{2}=0.90^{* *}$ DMDS $_{\text {LVAd }-2}=58.20196+0.15022 \mathrm{x}-0.00142 \mathrm{x}^{2} \mathrm{R}^{2}=0.92^{* *}$ $\mathrm{DMD}_{\mathrm{LVd}}=$ non-adjusted model

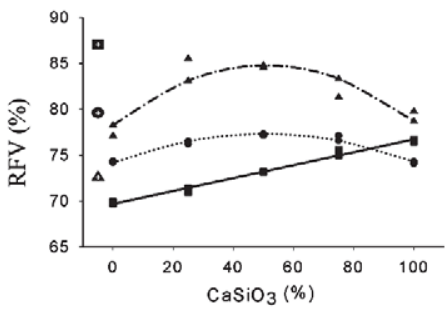

$\mathrm{RFV}_{\text {LVAd-1 }}=69.68980+0.07041 \times \mathrm{R}^{2}=0.97 * *$

$\operatorname{RFV}_{\text {LVAd-2 }}=78.26927+0.25704 \mathrm{x}-0.00253 \mathrm{x}^{2} \mathrm{R}^{2}=0.74 * *$

$\mathrm{RFV}_{\mathrm{LVd}}=74.17412+0.12430 \mathrm{x}-0.00123 \mathrm{x}^{2} \mathrm{R}^{2}=0.94 * *$

\section{$\square$ LVAd-1
LVAd-1 (without correctives)}

Figure 4 - Concentration of crude protein (CP), neutral detergent fiber (NDF) and acid detergent fiber (ADF), and dry matter digestibility (DMD), dry matter ingestion (DMI, in \% of body weight) and relative feed value (RFV) for palisade grass shoots, as a function of substitute proportions of the calcium carbonate by calcium silicate. ${ }^{* *}$ and ns $=p \leq 0.01$ and not significant $(p>0.05)$, respectively.

Jones, L.H.P.; Handreck, K.A. 1967. Silica in soils, plant and animals. Advances in Agronomy 19: 107-149.

Kaya, C.; Tuna, L.; Higgs, D. 2006. Effect of silicon on plant growth and mineral nutrition of maize grown under waterstress conditions. Journal of Plant Nutrition 29: 1469-1480.

Korndörfer, G.H; Arantes, V.A.; Corrêa, G.F.; Snyder, G.H. 1999. Effect of calcium silicate on soil silicon content and upland rice grain yield. Revista Brasileira de Ciência do Solo 23: 635-641. (in Portuguese, with abstract in English).

Klug, H.P.; Alexander, L.E. 1974. X-ray Diffraction Procedures for Polycrystalline and Amorphous Materials. John Wiley, New York, NY, USA.

Lackner, K.S. 2002. Carbonate chemistry for sequestering fossil carbon. Annual Review of Energy and the Environment 27: 193-232.

Liang, Y.C.; Chen, Q.; Liu, Q.; Zhang, W.H.; Ding, R.X. 2003. Exogenous silicon $(\mathrm{Si})$ increases antioxidant enzyme activity and reduces lipid peroxidation in roots of salt-stressed barley (Hordeum vulgare L.). Journal of Plant Physiology 160: 1157-1164.

Malavolta, E.; Vitti, G.C.; Oliveira, S.A. 1997. Assessment of Nutritional Status of Plants: Principles and Applications. 2ed. Potafos, Piracicaba, SP, Brazil. (in Portuguese).
Mali, M.; Aery, N.C. 2008. Silicon effects on nodule growth, dry-matter production, and mineral nutrition of cowpea (Vigna unguiculata). Journal of Plant Nutrition and Soil Science 171: 835-840.

Marschner, H. 1995. Mineral Nutrition of Higher Plants. Academic Press, London, England.

Matoh, T.; Kairusmee, P.; Tokahashi, E. 1986. Salt-induced damage to rice plants and alternation effect of silicate. Soil Science and Plant Nutrition 32: 295-304.

McKeague, J.A.; Cline, M.G. 1963. Silica in the soil. Advances in Agronomy 15: 339-396.

Melo, S.P.; Korndörfer, G.H.; Korndörfer, C.M.; Lana, R.M.Q.; Santana, D.G. 2003. Silicon accumulation and water deficit tolerance in Brachiaria grasses. Scientia Agricola 60: 755-759.

Mengel, K.; Kirkby, E.A. 2001. Principles of Plant Nutrition. 5ed. Kluwer Academic, Norwell, MA, USA.

Mehra, O.P.; Jackson, M.L. 1960. Iron oxide removal from soils and clays by a dithionite-citrate system buffered with sodium bicarbonate. Clays and Clay Minerals 7: 317-327.

Minson, D.J. 1971. Influence of lignin and silicon on a summative system for assessing the organic matter digestibility of Panicum. Australian Journal of Agricultural Research 22: 589-598. 
Minson, J.D. 1990. Forages in Ruminant Nutrition. Academic Press, New York, NY, USA.

Miyauchi, M.Y.H.; Lima, D.S.; Nogueira, M.A.; Lovato, G.M.; Murate, L.S.; Cruz, M.F.; Ferreira, J.M.; Zangaro, W.; Andrade, G. 2008. Interactions between diazotrophic bacteria and mycorrhizal fungus in maize genotypes. Scientia Agricola 65: 525-531.

Novais, R.F.; Smyth, T.J. 1999. Phosphorus in Soil and Plants under Tropical Conditions. Universidade Federal de Viçosa, Viçosa, MG, Brazil. (in Portuguese).

Ramos, L.A.; Nolla, A.; Korndörfer, G.H; Pereira, H.S.; Camargo, M.S. de. 2006. Reactivity of soil acidity correctives and conditioners in lysimeters. Revista Brasileira de Ciência do Solo 30: 849-857. (in Portuguese, with abstract in English).

Reis, G.L.; Lana, A.M.Q.; Maurício, R.M.; Lana, R.M.Q.; Machado, R.M.; Borges, I.; Quinzeiro Neto, T. 2010. Influence of trees on soil nutrient pools in a silvopastoral system in the Brazilian Savannah. Plant and Soil 329: 185-193.

Rodrigues, F.A.; McNally, D.J.; Datnoff, L.E.; Jones, J.B.; Labbe, C.; Benhamou, N.; Menzies, J.G. 2004. Silicon enhances the accumulation of dipertenoid phytoalexins in rice: a potential mechanism for blast resistance. Phytopathology 94: 177-183.

Schwertmann, U. 1964. The differentiation of iron oxides in soils by extraction with ammonium oxalate solution. Zeitschrift Pflanzenernähr Düng Bodenkd 105: 194-202. (in German).

Silva, D.J. 1998. Food Analysis: Chemical and Biological Methods. Universidade Federal de Viçosa, Viçosa, MG, Brazil. (in Portuguese).
Tisdale, S.L.; Nelson, W.L.; Beaton, J.D.; Havlin, J.L. 1993. Soil Fertility and Fertilizers. 5ed. Macmillan, New York, NY, USA.

Tokura, A.M.; Furtini Neto, A.E.; Curi, N.; Carneiro, L.F.; Alovisi, A.A. 2007. Silicon and phosphorus in soils cultivated with upland rice. Acta Scientiarum Agronomy 29: 9-16. (in Portuguese, with abstract in English).

Van Raij, B.; Cantarella, H.; Quaggio, J.A.; Ferreira, H.E.; Lopes, A.S.; Bataglia, O.C. 1987. Soil Chemical Analysis for Fertility Purposes. Fundação Cargill, Campinas, SP, Brazil. (in Portuguese).

Van Raij, B.; Cantarella, H.; Quaggio, J.A.; Furlani, A.M.C. 1996. Fertilization and Liming Recommendation for the State of São Paulo. 2ed. Instituto Agronômico de Campinas, Campinas, SP, Brazil. (in Portuguese).

Van Soest, P.J. 1994. Nutritional Ecology of the Ruminant. 2ed. Cornell University Press, Ithaca, NY, USA.

Wallace, A. 1989. Relationships among nitrogen, silicon, and heavy metal uptake by plants. Soil Science 147: 457-460.

Yoshida, S.; Ohnishi, Y.; Kitagishi, K. 1962. Chemical forms, mobility and deposition of silicon in rice plant. Soil Science and Plant Nutrition 8: 15-21.

Received April 26, 2010

Accepted January 20, 2011 